\title{
GCU
}

Glasgow Caledonian

University

University for the Common Good

\section{Of a time and place: Glasgow and its quality of life geographies}

McKendrick, John $\mathrm{H}$.

Published in:

Space and Polity

DOI:

10.1080/13562576.2020.1790351

Publication date:

2020

Document Version

Author accepted manuscript

Link to publication in ResearchOnline

Citation for published version (Harvard):

McKendrick, JH 2020, 'Of a time and place: Glasgow and its quality of life geographies', Space and Polity, vol. 24, no. 2, pp. 233-251. https://doi.org/10.1080/13562576.2020.1790351

\section{General rights}

Copyright and moral rights for the publications made accessible in the public portal are retained by the authors and/or other copyright owners and it is a condition of accessing publications that users recognise and abide by the legal requirements associated with these rights.

Take down policy

If you believe that this document breaches copyright please view our takedown policy at https://edshare.gcu.ac.uk/id/eprint/5179 for details of how to contact us. 
This is a pre-publication version of the paper. The published version (July 2020)

can be accessed here. More information about the journal can be accessed

\section{here.}

McKendrick, J.H. (2020) Of a time and place: Glasgow and its quality of life geographies, Space and Polity, 24.2: 1-19.

This paper reviews the work of the Glasgow Quality of Life Group, a limited life project (1986-1990) within the Applied Population Research Unit of the then Department of Geography and Topographic Science at the University of Glasgow. It explores the contribution of Ronan Paddison, and the wider innovations and impact of the group's work. It argues that these innovations were methodological, strategic, and challenged the prevailing wisdom of the day that understood GB to riven by a simple north-south divide, in which the 'north' was perceived to be the poorer partner in every way. Although of a time and place, the work of the GQLG remains pertinent to contemporary challenges and concerns.

\section{Of a time and place: Glasgow and its quality of life geographies}

Where we are at

Contemporary Scotland actively promotes the right of its people to express their opinion on matters that concern them. This is not to stake a claim to Scottish exceptionalism (Whateley, 2020), or to conflate talking and promoting participation with realising it (Pollok and Sharp, 2012), or to imply that there are not other wrongs to right and problems to address in Scotland (O'Hagan, 2017). However, participatory aspirations have been woven into the very fabric of the physical structure of the Scottish Parliament building and are embedded in the key principles that shape its functioning (Dewar, 1998). From the outset there 
has been concern to fashion a parliament in Scotland that is not only fair and accountable, but also one that is accessible and involves the people of Scotland in decision-making. Since its inception, evidence aplenty has emerged of Scotland seeking to be responsive to the concerns of its citizenry. The Community Empowerment (Scotland) Act 2015 was not only notable for strengthening the rights of communities to buy land, and extending provisions to enable this action; it also introduced powers to promote and facilitate public participation in resource allocation and decision-making in Scottish public bodies. The Scottish Elections (Reduction of Voting Age) Act 2015 reduced the voting age to 16 years old (from 18 years old) for the Scottish Parliament and local government elections in Scotland. Similarly, the GIRFEC (Getting it Right for Every Child) approach to working with children and delivering children's services (Scottish Government, 2018a), which has been pursued since 2006 and was most recently legislated through the Children and Young People (Scotland) Act 2014, revolves around the principle that the child or young person (and their family) is at the centre of decision-making in relation to services and support that pertains to them. How contemporary Scotland purports to function would have been of interest to Ronan Paddison, not least of all on account of his interests in community participation and civic engagement (Docherty et al., 2001).

Listening to the concerns of the people also underpins much of the anti-poverty activity in Scotland (McKendrick, 2018). The proliferation of Local Poverty Commissions across Scotland in recent years (e.g. Dundee Partnership, 2018) and the establishment of a national Poverty and Inequality Commission in 2019 (Poverty and Inequality Commission, 2019) not only hold power to account, but seek to 'speak truth to power' by involving people with direct experience of poverty. The guidance for the preparation of Local Child Poverty Action Reports (LCPARs) (Scottish Government, 2018b), which were introduced through the Child Poverty (Scotland) Act 2017 as part of the work to eradicate child poverty in Scotland by 2030, encourages the involvement of people with lived experience of poverty in order to better understand local issues and identify priorities.

However, encouragement does not always achieve the desired objective. In their review of the first round of these LCPARs, the Poverty and Inequality 
Commission $(2019,3)$ expressed concern noting that, [i]t was disappointing for us to note that 6 of the 10 reports we looked at did not mention involving people with direct lived experience. Whilst this in itself may not be evidence that engagement with people with direct lived experience did not take place it may, unfortunately be an indicator of a continuing failure to attach importance to such work". Furthermore, participation is not always sustained. Thus, there has been no repeat of the exemplar of good practice from 2016 when The Poverty and Truth Commission and the Scottish Government (2016) jointly developed an 'easy to read' summary of that year's annual release of new evidence on poverty in Scotland in which the testimony of experience complemented the presentation of 'hard evidence'.

Thus, despite general concern to enable people to express their opinion on matters that concern them, and the wide range of work to engage the voice of lived experience when working to tackle poverty in Scotland, it is hardly surprising that the two key tools that are used to evidence poverty and area deprivation in Scotland - the quadrennial Scottish Index of Multiple Deprivation (Scottish Government, 2016) and the annual release of national poverty statistics (Scottish Government, 2020) - remain rooted in the terra firma of (professional) expert opinion. It need not be so. This paper reviews the work of the Glasgow Quality of Life Group (GQLG) - of which Ronan Paddison was part - and concludes that its innovative approach could be revisited or rehabilitated to strengthen Scotland's wider ambitions of giving due weight to the concerns and considerations of its people. It also explores what might be viewed as an inherent contradiction in the GQLG approach - at once, democratic for encouraging a citizen-centric method for appraising wellbeing and expansive for appraising quality in life beyond narrow economic criteria, while also being complicit to the project of neoliberal urbanism (MacLeod, 2002) and all that this entails for marginalised populations (Smith, 1996). By way of introduction, the paper starts by contextualising this body of work in time and place, before characterising the GQLG's distinctive contribution to what had become known by the 1970s-1980s as 'quality of life' research, including in academic geography (Kuz, 1976; Helburn, 1982; Cutter, 1985). The GQLG contribution sought in effect 
to calibrate 'expert' defined objective evidence by taking seriously the views on such matters held by ordinary people living everyday lives. In what follows, given the context for the present paper in the special issue commemorating his academic life, Ronan Paddison will be referred to with the informal designation of 'Ronan'.'

Geographers creating quality of life geographies in, of and for Glasgow in the $1980 \mathrm{~s}$

As Ronan observed in 2009, the cities in which geographers work are a resource that provides opportunity, and shapes thinking and practice (Paddison, 2009). While this can be a dialectic in which the academy generates knowledge that is perceived by the city to be useful - demonstrated by Brown (1952) with reference to the Manchester Society of Commercial Geography - more commonly the return is one through which geographies (academic knowledge) are generated from what the city provides, such as the volume on the wider geography of the Glasgow region prepared by geographers from the university of Glasgow in 1958 (Miller and Tivy, 1958) or the way in which Harvey (1989) draws on the architecture of Baltimore to inform his thinking of the condition of postmodernity. Arguably, the utility of much of this knowledge remains within the confines of the academy and is an untapped resource for the wider city, if not its most marginalised groups (for an exception in Glasgow, see Holman, 1998).

In a similar fashion, Ronan drew upon the city of Glasgow in many ways over many years (Paddison, 1993; Paddison and Sharp, 2008; Pollock and Paddison, 2014), although much of his work could not be criticised for failing to provide a direct return for the city². Towards the end of the 1980s, the city of Glasgow was attempting to fashion a post-industrial future, having endured an acceleration of its de-industrialisation in the preceding decade (Craig, 2010). Thus, at the time of the establishment of the GQLG the team's immediate hinterland was one of a city negotiating an identity crisis (Boyle and Hughes, 1991), while transitioning to a new economic base (Boyle and Hughes, 1994). Regeneration had de- 
populated Glasgow and seemed to be failing many of those who were left behind (McKendrick, 2014). As Ronan himself observed in a landmark paper published in Urban Studies (Paddison, 1993), this was an era of urban entrepreneurialism, when cities sought 'competitive advantage' by promoting and exploiting their strengths to attract 'footloose services' that were understood to be the basis for future prosperity (Kearns and Philo, 1993). To achieve this, it was widely understood - and actively promoted by the UK Government of the day (DoE and DoE, 1998) - that the private sector was required to take a more active role in shaping city futures. Against this context, quality of life had obvious appeal as a tool that might be used to re-position the city to arrest population decline (Findlay and Rogerson, 1993) and enhance competitiveness (Rogerson, 1999). Pacione (1999) acknowledges that these experiences were not unique to Glasgow and were shaped by forces operating at the full gamut of geographical scales from the local through global, arguing that this amounted to no less than a social and economic transformation for the city.

From this city in flux in the late $20^{\text {th }}$ Century, was spawned two very different 'quality of life' geographies. From the University of Strathclyde, physically located at the heart of the city, the prolific Michael Pacione built on the traditions of welfare geography (Smith, 1974) and used the tools provided by the quantitative revolution (Billinge et al., 1984) to examine quality of life in the city of Glasgow. While some of his work explored related issues - such as the role of faith communities in tackling social inequality (Pacione, 1990a, 1991) or focusing on rural Scotland (Pacione, 1995) - his primary contribution was in charting the micro-geographies of poverty and deprivation across the city of Glasgow. Conceiving of this as an urban crisis (Pacione, 1989) and focusing on the role of public policy (Pacione, 1987), he demonstrated both the persistence of poverty in place (Pacione, 2004) and the migration of the 'urban crisis' from the core to the periphery of the city (Pacione 1986,1990b). Although more than able to apply the geographer's keen eye to understand the city through direct experience (Pacione, 2009), and not averse to canvassing the opinions of citizens and factoring this into analysis (Pacione, 1984), Pacione's favoured approach was the multivariate analysis of Census data. Largely based on the analysis of 
objective conditions, Pacione drew attention to the inequalities within Glasgow, portraying a city that was divided and failing too many of its citizens. By definition, in Glasgow and undoubtedly of Glasgow, the extent to which Pacione's geographies were used for Glasgow is open to critique. Drawing impetus from the same geographies, a very different approach to quality of life emerged across the city, in its West End, from academics working at the University of Glasgow.

\section{The work of the Glasgow Quality of Life group}

The Glasgow Quality of Life Group (GQLG) was a limited life project (1986-1990) within the wider Applied Population Research Unit (APRU) in what was then called the Department of Geography and Topographic Science at the University of Glasgow. Emerging from a project funded by Glasgow Action ${ }^{3}$, the group administered three rounds of national surveys across Great Britain, ranking large cities (Findlay et al., 1988), intermediate cities (Rogerson et al., 1989a) and non-metropolitan district councils (Rogerson et al., 1990a) (Figure 1) in terms of 'where the average person can get what they want'.

(insert Figure 1 about here)

Figure 2 is how the GQLG described its approach. In effect, it is a three-stage process. First, a public opinion survey is administered, with a nationally (British) representative sample, to establish the importance to the 'average person' of pre-defined quality of life 'dimensions'. Data on local conditions for each 'dimension' is collected for each place in the second stage. In the third and final stage, the subjectively defined and nationally representative opinions of stage one are used as weightings, which are applied to the objective measures of local conditions (the local indicators of the second stage). The aggregation of the weighted scores for each dimension (the product of the weighting applied to the indicator) generates a quality of life score for each place, facilitating comparison across defined geographical cohorts (such as cities of comparable size, or non- 
metropolitan district councils). In effect, the GQLG asked people what was important to them, then found out which places could best provide this.

(insert Figure 2 about here)

Notwithstanding its apparent simplicity, it was a method that was initially developed following immersion in the wider literature and thereafter refined over several years. Significantly, the 'dimensions' of the index were not solely expert-defined. Rather, for the initial study of large cities, a pilot study canvassed opinion among the wider public on what aspects of the urban environment were important to quality of life. From this 21 dimensions were identified. Only then, was the national opinion survey deployed to canvass 1200 people across $\mathrm{GB}^{4}$, inviting participants to either indicate that the dimension did not matter to them, or to rate it on a scale from 1 (minimal importance) to 5 (very great importance). A threshold of more than $6 \%$ of respondents zero-rating a dimension (indicating that it was not important to them) led to exclusion of that dimension from the final index; on this basis, the dimensions in the index were reduced to 20 , as 'Housing Association accommodation' did not matter to too many of the British public.

(insert Table 1 about here)

The second-stage task of compiling the objective indicators of local conditions should not be under-estimated. For some 'dimensions' a single indicator was used (e.g. violent crime, access to council housing), while for others multiple indicators were used (e.g. the objective evidence for five of the dimensions comprised four indicators). In total, 48 indicators across the 20 dimensions were used in the final index (Table 1). ${ }^{5}$ Indicators for each of the 'dimensions' of interest to the GQLG were not always accessible as off-the-shelf statistics, with a minority requiring laborious manual searching and compilation. For example, much manual labour was involved in counting the number of youth clubs per head of the 10-19 year old population (one of the four 'leisure facilities' indicators), which was not already enumerated and available as a geographically 
referenced statistic. Table 1 summarises key information for each of the 20 dimensions that comprised the GQLG index. The critical values are the national weightings in column $\mathrm{C}$, which were used in the calculation of the quality of life index. The table also details the indicators for each 'dimension' (column I), specifies national ranks for each dimension in descending order of importance (column C), presents alternative weightings and ranks for the Scottish subpopulation (columns $\mathrm{E}$ and $\mathrm{F}$ ), identifies for which dimensions there is significant difference in opinion over the importance of dimensions between Scottish and other sub-populations (columns $\mathrm{G}$ and $\mathrm{H}$ ), and reports the proportion of the national population who gave each dimension the highest rating of ' 5 ' or 'very great importance' (column B).

The final stage comprised two steps. First, the stage one weightings were applied to the stage two standardised indicators to generate interim quality of life values for each dimension. Thereafter, these 20 dimension sub-totals were aggregated into an overall quality of life measure. Although the GQLG published methodological papers (e.g. Rogerson et al., 1989c) and accounted for their methods in each of their empirical papers (e.g. Findlay et al., 1988b), their writing lacks detail on the standardization procedures that enabled multiple indicators to be used to generate objective totals for each dimension, that were thereafter weighted. We are only advised that the final rank position of the cities reflects the "sum of the product scores" (Findlay et al., 1988b, 271).

(insert Figure 3 about here)

The product of these manipulations and calculations were rankings of places according to whether they were best placed to deliver what people wanted. At times, the GQLG is bold in its interpretation, claiming for example that the results presented here in Figure 3, “... shows where the best quality of life can be found, and where a person or family on the move ought to consider locating if presented with a choice of residence" Findlay et al. (1988, p.271, original emphasis), and contrasting this with the ratings of mental map work, which it is asserted are skewed by, “... people’s feelings about specific places, ... reflect[ing] 
the public's bias, misinformation and lack of knowledge about the qualities of British cities". Figure 2 reproduces a map of this ranking when the methodology was applied in the first round to mainland Britain's largest cities, revealing that Edinburgh came out first overall from this geographical cohort, being the 'best', while Glasgow - the home of the research - could only manage twenty-fifth and hence ranked in the second lowest quintile of cities. Notably, Glasgow is an outlier among cities from the Celtic fringe, with the others comprising the five highest rank cities (in addition to Edinburgh, Aberdeen was ranked 2; Plymouth, 3; Cardiff, 4 and Motherwell 5).

Issues could be raised over the method. The extent to which the indicators truly represent the dimensions could be challenged. Although the use of national weightings can be justified by the strong correlations when comparing across regions (Morris et al., 1988), there was significant variation in the ratings between migrants and non-migrants (Findlay and Rogerson, 1993), and clearly the dimensions would fail to reflect the concerns of Housing Association tenants. Statistical pursists may recoil at calculation of an average weighting from ordinal data. And, it may be questioned whether different national weightings should have been applied for large cities and intermediate cities, given that a new round of weightings were used in the third round for non-metropolitan districts councils. On the other hand, the GQLG was transparent, robust and delivered innovation and impact.

The innovations and impact of the Glasgow Quality of Life group

It seems apt to start a review of the GCLG's work with some numbers.

Collectively, the body of work has been cited more than 1400 times, with for example, Ronan's co-authored paper on Class, consumption and quality of life (Rogerson et al., 1996) being cited by scholars of architecture, consumer studies, economics, environmental biology, environmental management, housing studies, planning, psychology, public health, recreation management, social policy, sociology, technology studies and urban studies from Australia, Belgium, Canada, 
Czech Republic, Indonesia, Italy, Malaysia, Poland, Portugal, Saudi Arabia, Serbia, Taiwan, Turkey, USA, South Africa, South Korea, as well as geography in the UK, and with new citations to this paper added every single year since 1997, bar 2004. The broad academic reach of the work was matched by the public interest and reception in the findings. Each release was met with a flurry of media interest, although calls from local media stations in the Midlands of England were usually more critical of the rankings, which tended to portray their locales as ones that were failing to provide what people wanted. In contrast, it is no accident that Aberdeen (rank 2, large cities), Cardiff (rank 4 , large cities), Swindon (rank 7, intermediate Cities) and Kyle \& Carrick (rank 2, District Councils) were among those authorities requesting a bespoke report, given their high rankings on their league table. ${ }^{6}$

From a contemporary vantage point, it is not difficult to identify ways to improve or refine the method, or to question whether the findings are still valid. The contribution of the GQLG body of work, set in the context of more recent attempts to conceptualise and measure 'sustainable' quality of life in an English context, receives quite systematic evaluation in Higgins and Campanera (2011). They use sustainable quality of life data from the Audit Commission's local quality of life indicators database to draw comparisons with the work of the GQLG from twenty years previous. Although finding value in the work of the GQLG (a pre-condition of the paper, which aimed to use the GQLG findings to compare change through time), fault was found. The GQLG indicators for climate change were judged to be weak, and a pre-occupation with input, rather than outcome indicators was identified. Furthermore, no discernible patterns between the GQLG findings and their own results are identified for larger cities, giving rise to the possibility of a north-to-south shift in quality of life for large English cities in the intervening twenty years. However, contemporary queries and criticisms do not detract from the innovations of the GQLG's work, which were arguably threefold.

First and foremost, the work of the GQLG was methodologically innovative (Rogerson et al., 1989). Previous quality of life studies had tended to favour 
using supposedly objective indicators of factors reckoned a priori by experts (social scientists, policy-makers) to shape quality of life, typically inflected by a belief that economic variables, notably employment rates or home ownership rates, were decisive. As Rogerson et al. (1989, p.228) noted, such studies avoided direct engagement with "more personalised (and arguably intangible) aspects of life as actually experienced by people within their urban environments."

This approach was a significant departure from work at that time that tended not to fuse the subjective and objective (Kuz, 1978), whereas such a fusing of the two was precisely what the GQLG attempted from the outset. That said, Findlay et al. (1988) still appeared hesitant about fully embracing the subjectivity of people's experiences and, as in their distancing from 'mental maps' in the Gould and White (1974) tradition, the role of feelings in potentially 'biasing' a quality of life study. In a later development of this approach (McKendrick, 1998), an individual lone parent's weightings of what mattered to them were applied to their own subjective assessment of their life experiences. A multiple-additive model of quality of life was then generated, which is the sum of satisfaction with life experiences, weighted according to the importance given to that life experience by that individual. This was a further democratisation of the approach that brought comparative quality of life studies closer to the experiences, if not necessarily the deeper emotional life of, those they purported to represent.

The second innovation was strategic, with positive outcomes that were internal and external to the Department of Geography and Topographic Science at the University of Glasgow. A claim could be made that the GQLG established the first set of quality of life rankings for cities that had a 'scientific' basis, which gave credence to policy impact, as quality of life began to feature on local agendas, providing the case for some to exploit for competitive advantage what appeared to be an environment that delivered what people wanted. Interestingly, Findlay et al. (1988, p.270) did wonder "whether or not researchers should participate in any exercise involving performance indicators ... because [of] the potential abuses of such work" when translated into wider circles of politics and policy, although 
this was actively encouraged in other work. For example, the preface to the report of the third round, indicated that "[t]he Group is happy to undertake new consultancy research for companies and government agencies ... on issues pertaining to urban and rural quality of life" (Rogerson et al., 1990a, 1). Internally, although from the vantage of 2020, there appears nothing remarkable about income generation and research funded as consultancy by external agencies, at the time this was unusual and arguably transformative for the Department. This new income stream not only sustained research capacity, but also provided evidence of what was an innovative research environment for the purposes of the then still fledgling UK national Research Assessment Exercise (RAE). With much media attention granted to the results, the GQLG work also raised the profile of the Department's research, within the wider university and beyond.

Finally, the work of the GQLG challenged the prevailing understanding of what determined quality of life, and the geographies of quality of life across Great Britain. The work was undertaken at a time when there much was concern with the so-called 'north-south divide,' in which social conditions and economic performance was viewed to be poorer in the north, meaning northern England extending into Scotland. As Ronan himself recognised (Boyle et al., 2018), these are concerns that still prevail today, with the 'Northern powerhouse' (Lee, 2017; Martin and Gardiner, 2018) and 'City Deals' (Jones et al., 2017; Beel et al., 2018) being the latest concepts to be promoted to re-balance the UK. While not to dispute these imbalances, the work of the GQLG enhanced our understanding of the north-south divide in two important ways (McKendrick, 1995). First, it provided evidence for a Celtic periphery in which experiences in Scotland, Wales and Cornwall could be contrasted with the core in England. A simple northsouth divide was found wanting as an analytical device. Second, and most significantly, a paradox was identified in which, despite evidence of more deprivation and less prosperity, this Celtic periphery was found to be more likely to provide what people wanted. As other work within the group clearly demonstrated (McKendrick, 1998), there is still quality of life to be found amidst poverty and deprivation. Underpinning these challenges to prevailing thought 
was the evidence that economic considerations, while important, were relatively less important in determining what contributed to quality of life; crime levels, health, pollution levels, shopping facilities and education provision were also weighted more heavily in the GQLG index on account of the higher importance accorded by the British public to these dimensions, relative to wage levels, employment prospects and unemployment levels. Later work (McKendrick, 1998) extended this point among lone parents, finding that family life and control over life were among the three most important factors shaping their quality of life, with family life exerting positive impact, in contrast to the mixed impact of control over life.

\section{The Paddison effect}

Although a collective, the particular interests of GQLG members can be discerned from the work of the group, e.g. Allan Findlay and migration (Findlay and Rogerson, 1993) and Robert Rogerson and urban studies (Rogerson, 1999). Ronan joined the GQLG in 1989, co-authoring five papers (Morris et al., 1989; Findlay et al., 1989, 1990; Rogerson et al., 1989b, 1996) and four reports (Rogerson et al., 1989b, 1990b, 1990c, 1990d) on the geographies of quality of life across Great Britain.

Ronan's wider interests in political and urban geography enabled the GQLG to explore how local government and other bodies, which were concerned with place promotion, could use quality of life rankings for competitive advantage. This became a source of income as local authorities commissioned bespoke GQLG reports (Rogerson et al., 1990a, 1990b, 1990c), and emerged as the central focus of much of the GQLG writing thereafter (notably Rogerson et al., 1996; Rogerson, 1999). Robert Rogerson (personal communication) credits Ronan for enabling this, by shaping how the group actively engaged officers within local government, and generated outputs that met their particular needs. Notwithstanding the concern noted earlier about possible 'abuses' of the GQLG's efforts, Rogerson et al. (1989) - one of the papers where Ronan was a co-author 
- acknowledged that, "[w]hile some cities [have] used the results to promote the 'image' of the city, other local authorities [have] commissioned more detailed studies to examine weaknesses in 'their' city with a view to identifying prescriptive measures to improve the overall quality of life of their citizens." Ronan's influence can perhaps be detected here, suggesting ways in which quality of life work can move beyond being a tool of competitive 'place-marketing' - and 'urban entrepreneurialism' - to making a contribution more attuned with geography's welfare traditions..

Indeed, although the ranking of cities continued after Ronan joined the GQLG, there is a discernible shift in focus away from the descriptive reporting of findings to more discursive and theoretically informed consideration of their significance. That is most clearly evident in the 66 page monograph for Progress in Planning. Here, the GQLG work is related to a wider body of academic thought that will be familiar to followers of Ronan's work. As the title of publication suggests, the objective of this monograph was to connect the GQLG's work with wider debates on social stratification in Britain, focusing on the ways and extent to which consumption cleavages were undermining traditional class-based divisions. In particular, chapter 4, which uses Glasgow to show how city marketing and positioning (drawing on quality of life narrative) can be used as part of the armoury that can transition formerly industrial cities to a servicebased economy. Although with a keen focus on impact and practical utility, it is carefully positioned against the prevailing academic thought of the day.

In the final analysis, the GQLG's body of work had a reach far beyond Glasgow, although it remained sensitive to what it implied for the city; in comparison to the quality of life geographies across the city of Pacione, although also a geography from Glasgow (in the city), the GQLG's work is less centrally focused on it (of the city, but to a lesser extent than Pacione). With initial funding from Glasgow Action and a keenness to engage city leaders and decision-makers, it was undoubtedly a quality of life geography for the city (moreso than Pacione), although whether this was in the service of its most marginalised is open to question. 


\section{Conclusion: Recovering from lost geographies}

Three decades on from the dissolution of the GQLG, the public appetite for all manner of rankings remains as strong as ever, as does the veracity of their critique. The United Nations' Sustainable Development Goals encourage global and national attention on improving performance for the indicators that have been selected to represent each of the 17 Goals. These sit alongside longstanding global metrics, such as the Human Development Index (UNDP), World Happiness Report (Sustainable Development Solutions Network), and others which provide alternatives to narrowly specified measures of GDP. Even concepts of prosperity are challenged with the UCL Institute for Global Prosperity and the Legatum Institute both proposing global prosperity indices that blend economic and social wellbeing. Thus, interest in geographies of wellbeing and happiness have been reignited (e.g. Ballas, 2013; Ballas and Dorling, 2013; Smith and Reid, 2018). These have also been fuelled by political agendas that, for both progressive reasons and equally ones perhaps looking to deflect attention from economic hardship and inequity, want to explore and promote qualities of life beyond the economic; in seems incongruent that the UK Government introduced their Measuring National Wellbeing Programme, at the point at which Austerity was introduced and shortly before it withdrew from a national commitment to eradicate child poverty by 2020. In an era of 'big data', we are now better placed to examine geographical variations than in the era when GQLG researchers trawled through multiple sources to generate local indicators for quality of life indices. In some respects, there is stronger public appetite and we are now better placed to address the interests of the GQLG than it was in its time.

Beyond the academy, the participatory ethic infuses how we design, deliver and evaluate services. However, all is not well; a disconnect might be observed in the broad field of anti-poverty work. It is now considered a necessity to engage those with lived experience when researching the conditions of poverty and 
deprivation. Quite rightly, this has encouraged research and activity that utilises techniques better placed than large-scale quantitative datasets to learn from lived experience, However, it has failed to displace the central importance of number and ranking in tracking change and measuring incidence. Although there are attempts to use the former to facilitate understanding of the latter, this falls short of the approach promoted by the GQLG, which sought to factor in the preferences of the populous when measuring quality of life outcomes. The key metrics that are used to appraise poverty and area deprivation in Scotland do not factor into the analysis what people think is important, or do so in a way that is marginal. The GQLG also found that weightings had a limited impact on rankings, but had significant value in terms of legitimising the approach. In an era when we valorise meaningful participation, and when citizen science is being regarded more favourably than it has for many years, the contributions of Ronan Paddison and the wider GQLG still have much to offer in strengthening how we use data better to reflect what matters to the people we purport to represent. 


\section{Acknowledgements}

John is grateful to Mark Boyle and Chris Philo for affording him the opportunity to share his thoughts on Ronan and his work, and for commenting on an earlier draft of this paper. Eugene McCann kindly reviewed the final draft. Lesley Garrick, Fiona Smith and, in particular, Robert Rogerson, provided insight into Ronan's contribution to the work of the GQLG.

\section{References}

Ballas D and Dorling D (2013) The geography of happiness. In: David SA, Boniwell I and Conley Ayers A (eds) Oxford Handbook of Happiness. Oxford: Oxford University Press, 465-481.

Ballas, D. (2013) What makes a 'happy city'? Cities, 32 (Suppl.1), S39-S50.

Beel, D., Jones, M., \& Rees Jones, I. (2018) Elite city-deals for economic growth? Problematizing the complexities of devolution, city-region building, and the (re) positioning of civil society. Space and Polity, 22(3), 307-327.

Billinge, M., Gregory, D. and Martin, R. eds. (1984) Recollections of a Revolution: Geography as Spatial Science. London: Macmillan.

Boyle, M. and Hughes, G., 1991. The politics of the representation of 'the real': discourses from the Left on Glasgow's role as European City of Culture, 1990. Area, pp.217-228.

Boyle, M. and Hughes, G., 1994. The politics of urban entrepreneurialism in Glasgow. Geoforum, 25(4), pp.453-470.

Boyle, M., Paddison, R., \& Shirlow, P. (2018). Introducing 'Brexit Geographies': five provocations. Space and Polity, 21(2), 97-110.

Boyle, R. (1989) Partnership in practice-An assessment of public-private collaboration in urban regeneration-a case study of Glasgow Action. Local Government Studies, 15(2), 17-28.

Brown, T.N.L., 1952. The Manchester Society of Commercial Geography. The Journal of the Manchester Geographical Society, 57, pp.40-45.Child Poverty (Scotland) Act 2017 (asp 6) [online], [viewed $4^{\text {th }}$ June 2020]. Available at: http://www.legislation.gov.uk/asp/2017/6/contents/enacted.

Children and Young People (Scotland) Act 2014 (asp 8) [online], [viewed $4^{\text {th }}$ June 2020]. Available at:

http://www.legislation.gov.uk/asp/2014/8/introduction/enacted.

Community Empowerment (Scotland) Act 2015 (asp 6) [online], [viewed $4^{\text {th }}$ June 2020]. Available at:

http://www.legislation.gov.uk/asp/2015/6/contents/enacted

Craig, C. (2010) The Tears That Made the Clyde. Argyll Publishing. 
Cullen, G., \& McKinsey, I. (1985). The Potential of Glasgow City Centre. McKinsey.

Cutter, S. (1985) Rating Places: A Geographical View of Quality of Life. Association of American Geographers Resource Publication, Washington DCDepartment of Environment and Department of Employment (1987) Action for Cities: Building on Initiative. London: HMSO.

Dewar, D. (1998) The Scottish Parliament, Scottish Affairs, 25(2), 4-12.

Docherty, I., Goodlad, R. \& Paddison, R. (2001) Civic culture, community and participation in contrasting neighbourhoods, Urban Studies, 38, 2225-2250.

Dundee Partnership (2018) Dundee Fighting for Fairness. Dundee: Dundee Partnership. [viewed $4^{\text {th }}$ June 2020]. Available at: https://www.dundeefightingforfairness.co.uk/reports

Findlay, A.M, \& Rogerson, R. (1993). Migration, places and quality of life: voting with their feet. Population matters, 33-49.

Findlay, A.M., Rogerson, R. J., \& Garrick, L., Morris, A.S. \& Paddison, R. (1990) Pulling rank. Geographical Magazine, 62, 42-44.

Findlay, A.M, Rogerson, R., Paddison, R., \& Morris, A. (1989) Whose quality of life? The Planner, 75(15), 21-2.

Findlay, A., Rogerson, R., \& Morris, A. (1988a). In what sense 'indicators' of quality of life?. Built Environment, 14(2), 96-106.

Findlay, A.M., Rogerson, R.J. \& Morris, A.S. (1988b) Quality Of Life In British Cities In 1988, Cities, 5: 268-276.

Findlay, A.M, Rogerson, R., Morris, A. \& Paddison, R (xxxx) Teaching quality of life: The geographical issues. SAGT Journal, $\mathrm{xx}, 9-14$.

Harvey, D. (1989) The condition of postmodernity. Oxford: Blackwell.

Helburn, N. (1982) Geography and the quality of life. Annals of the Association of American Geographers, 72(3), 445-456.

Higgins, P. and Campanera, J.M. (2011) (Sustainable) quality of life in English city locations, Cities, 28(4), 290-299.

Holman, B. (1998) Faith in the Poor. Lion Publishing.

Jones, P., Hillier, D., \& Comfort, D. (2017) City deals in Scotland. Town and Country Planning, 212-218.

Kearns, G., \& Philo, C. (1993) Selling Places: The city as cultural capital, past and present. Pergamon.

Kuz, T. (1978) Quality of life: an objective and subjective variable analysis. Regional Studies, 12, 405-417.Lee, N. (2017) Powerhouse of cards? Understanding the 'Northern Powerhouse'. Regional Studies, 51(3), 478489.

MacLeod, G. (2002) From urban entrepreneurialism to a "revanchist city"? On the spatial injustices of Glasgow's renaissance. Antipode, 34(3), 602-624.

Martin, R., \& Gardiner, B. (2018) Reviving the 'Northern Powerhouse' and spatially rebalancing the British economy: the scale of the challenge. 
In Berry, C. and Giovannini, A., eds. Developing England's North: the Political Economy of the Northern Powerhouse. Palgrave Macmillan. 23-58.

McKendrick, J.H. (1995) Poverty and the Celtic divide. In Philo, C. (ed.) Off the map: the social geography of poverty in the UK. London: Child Poverty Action Group. 45-64.

McKendrick, J.H. (1998) The big picture: quality in the lives of lone parents. In Ford, R. and Millar, J. (eds.) Private lives and public responses: Lone parenthood and future policy in the UK. Bristol: Policy Press. 78-103.

McKendrick, J.H. (2014) A Red Road to Regeneration for Scotland? A Common Weal Approach to Urban Regeneration. [online] Glasgow: Common Weal. [viewed $4^{\text {th }}$ June 2020]. Available at: https://commonweal.scot/policylibrary/red-road-regeneration-scotland

McKendrick, J.H. (2018) Listening to the Lived Experience of Poverty in Scotland. An Evidence Review of Issues Pertaining to Income, Expenditure and Wealth. Report for the Poverty and Inequality Commission. Glasgow: SPIRU. [viewed $4^{\text {th }}$ June 2020]. Available at: https://povertyinequality.scot/wpcontent/uploads/2019/04/SPIRU-Final-Report.pdf.

Miller, R., and Tivy, J. 1958. Glasgow and its Region (Ed.) Miller R. and Tivy J, T\&A Constable.

Morris, A., Findlay, A., Paddison, R., \& Rogerson, R. (1989) Urban quality of life and the north-south divide. Town and country planning, 58(7/8), 207-10.

O'Hagan, A. (2017) Gender budgeting in Scotland: A work in progress. Administration, 65(3), 17-39.

Pacione, M. (1986) The changing pattern of deprivation in Glasgow. Scottish Geographical Magazine, 102(2): 97-109.

Pacione, M. (1987) Multiple deprivation and public policy in Scottish cities: an overview. Urban Geography, 8(6): 550-576.

Pacione, M. (1989) The urban crisis: poverty and deprivation in the Scottish city. Scottish Geographical Magazine, 105(2): 101-115.

Pacione, M. (1990a) The ecclesiastical community of interest as a response to urban poverty and deprivation. Transactions of the Institute of British Geographers, 15(2): 193-204.

Pacione, M. (1990b) A tale of two cities: the migration of the urban crisis in Glasgow. Cities, 7(4): 304-314.

Pacione, M. (1991) The church urban fund: a religio-geographical perspective. Area, 23:101-110.

Pacione, M. (1995) The geography of deprivation in rural Scotland. Transactions of the Institute of British Geographers, 20(2):173-192.

Pacione, M. (2004) Environments of disadvantage: Geographies of persistent poverty in Glasgow. Scottish Geographical Journal, 120(1-2): 117-132.

Pacione, M. (2009). The view from the tower: geographies of urban transformation in Glasgow. Scottish Geographical Journal, 125(2), 127-181. 
Paddison, R. \& Sharp, J. (2008) Questioning the end of public space: reclaiming control of local banal spaces, Scottish Geographical Journal, 123, 87-106.

Paddison, R. (1993) City marketing, image reconstruction and urban regeneration, Urban Studies, 30, 339-349.

Paddison, R. (2009) 'The other Glasgow: reflections on teaching a city' In Recollections and Reflections, Scottish Geographical Journal, 125 (3-4), 339343.

Pollock, V. \& Paddison, R. (2014) On place-making, public art and participation: the Gorbals, Glasgow, Journal of Urbanism, 7, 85-105.

Pollock, V. L., \& Sharp, J. (2012) Real participation or the tyranny of participatory practice? Public art and community involvement in the regeneration of the Raploch, Scotland. Urban Studies, 49(14), 3063-3079.

Poverty and Inequality Commission (2019a) Poverty and Inequality Commission's Review of the Local Child Poverty Action Reports [online]. Poverty and Inequality Commission. [viewed $13^{\text {th }}$ June 2020]. Available at: https://povertyinequality.scot/wp-content/uploads/2019/11/Povertyand-Inequality-Commission-review-of-the-local-child-poverty-actionreports.pdf

Poverty and Inequality Commission (2019b) What we do [online]. Poverty and Inequality Commission. [viewed $4^{\text {th }}$ June 2020]. Available at: https://povertyinequality.scot/what-we-do/.

Rogerson, R.J. (1999) Quality of life and city competitiveness. Urban Studies, 36(5-6), 969-985

Rogerson, R. (1999b). Quality of life, place and the global city. Urban Quality of Life: Critical Issues and Options, University of Singapore Press, Singapore, 13-31.

Rogerson, R. J., Findlay, A. M., Paddison, R. \& Morris, A. S. (1996) Class, consumption and quality of life. Progress in Planning, 1(45), 1-66.

Rogerson, R., Findlay, A., Morris, A., \& Paddison, R. (1989b) Variations in quality of life in urban Britain: 1989. Cities, 6(3), 227-233.

Rogerson, R., Findlay, A.M., Morris, A.S. \& Paddison, R. (1990b) Stockton On Tees And Other District Councils In Britain: A Comparative Study Of Quality of Life; Glasgow: G.Q.L.G., University of Glasgow.

Rogerson, R., Findlay, A.M., Morris, A.S. \& Paddison, R. (1990c) Swindon And Other District Councils In Britain: A Comparative Study Of Quality Of Life; Glasgow: G.Q.L.G., University of Glasgow.

Rogerson, R., Findlay, A.M., Morris, A.S. \& Paddison, R. (1990d); Kyle \& Carrick And Other District Councils In Britain: A Comparative Study Of Quality of Life; Glasgow: G.Q.L.G., University of Glasgow

Rogerson, R., Morris, A., Findlay, A., \& Paddison, R. (1989a) Quality of life in Britain's intermediate cities. Glasgow Quality of Life Group, Department of Geography, University of Glasgow, Glasgow. 
Rogerson, R., Morris, A., Findlay, A., \& Paddison, R. (1990a) Quality of life in Britain's District Councils. Glasgow Quality of Life Group, Department of Geography, University of Glasgow, Glasgow.

Rogerson, R.J., Findlay, A.M., Morris, A.S., \& Coombes, M.G. (1989c). Indicators of quality of life: some methodological issues. Environment and Planning A, 21(12), 1655-1666.

Scottish Elections (Reduction of Voting Age) Act 2015 (asp 7) [online], [viewed $4^{\text {th }}$ June 2020]. Available at: http://www.legislation.gov.uk/asp/2015/7/contents/enacted

Scottish Government (2016) SIMD16 Technical Notes. [online]. Edinburgh: Scottish Government. [viewed $4^{\text {th }}$ June 2020]. Available at: https://www2.gov.scot/Resource/0050/00504822.pdf.

Scottish Government (2018a) Getting it right for every child [online], Scottish Government. [viewed $4^{\text {th }}$ June 2020]. Available at: https://www.gov.scot/policies/girfec/

Scottish Government (2018b) Child Poverty Act - CPB Local Action Plans Guidance-June 2018 - Revised. [online]. Edinburgh: Scottish Government. [viewed $4^{\text {th }}$ June 2020]. Available at: https://www.gov.scot/publications/local-child-poverty-action-reportguidance/.

Scottish Government (2020) Poverty and Income Inequality in Scotland 2016-19. [online], Scottish Government. [viewed $4^{\text {th }}$ June 2020]. Available at: https://www.gov.scot/publications/poverty-income-inequality-scotland2016-19/.

Smith, D.M. (1974) Who gets what where, and how: a welfare focus for human geography. Geography, 59: 289-297.

Smith, N. (1996). The New Urban Frontier: Gentrification and the revanchist city. New York: Routledge.

Smith, T.S.J. and Reid, L. (2018) Which 'being' in wellbeing? Ontology, wellness and the geographies of happiness, Progress in Human Geography, 42(6), 807-829.

The Poverty Truth Commission and Scottish Government (2016) Poverty in Scotland. Edinburgh: Scottish Government. [viewed $4^{\text {th }}$ June 2020]. Available at: https://www.gov.scot/publications/poverty-scotland/

Whateley, I. (2020) Scottish identity, nationalism and the dangerous myth of Scottish exceptionalism [online], The Social Review, [viewed $4^{\text {th }}$ June 2020]. Available at: https://www.thesocialreview.co.uk/2020/01/10/scottishidentity-nationalism-and-the-dangerous-myth-of-scottish-exceptionalism/ 
Figure 1: GQLG Report on Quality of Life in Britain's District Councils

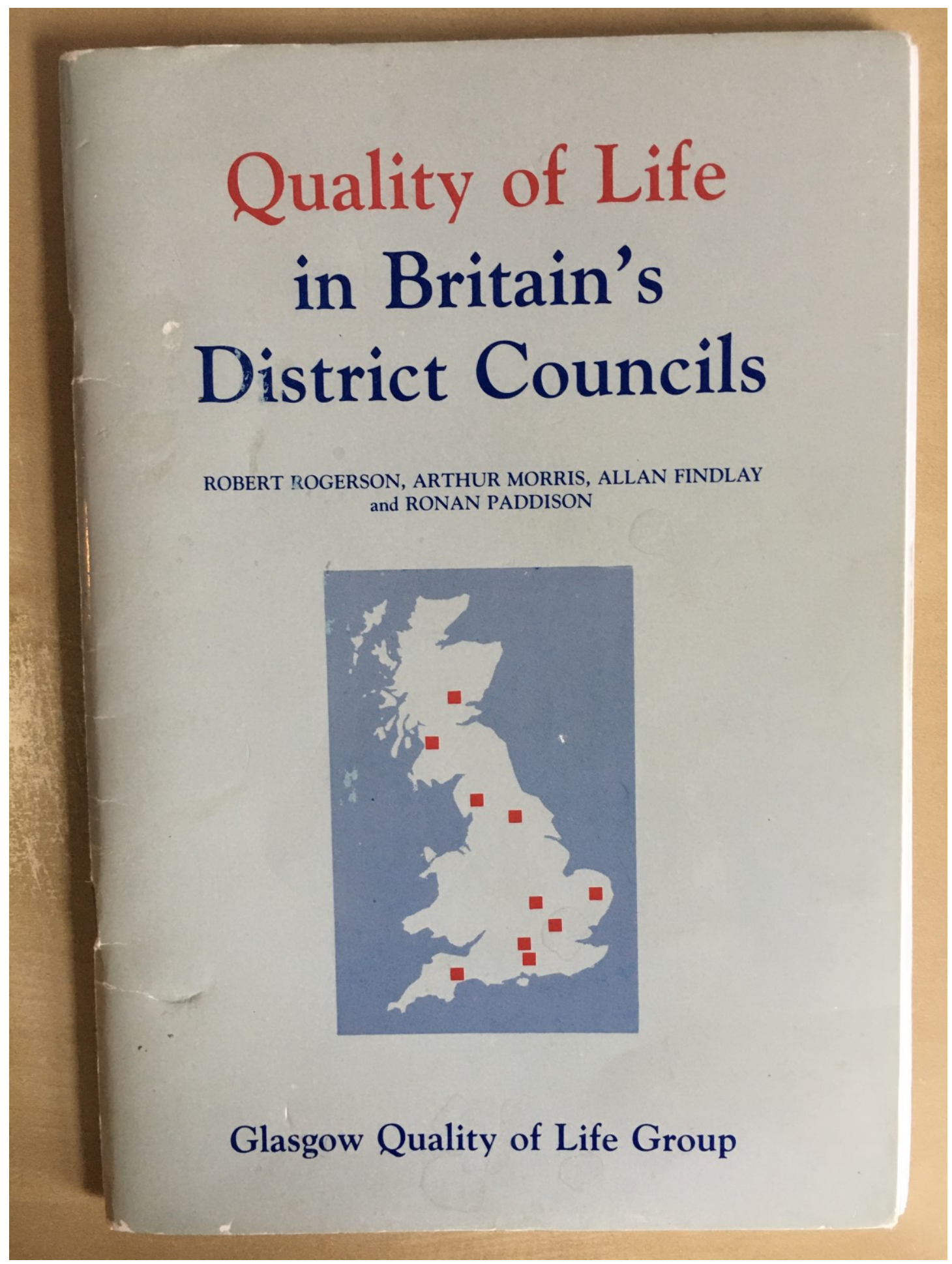

Source: Rogerson et al. (1990a) 
Figure 2: Glasgow Quality of Life Group: research methodology

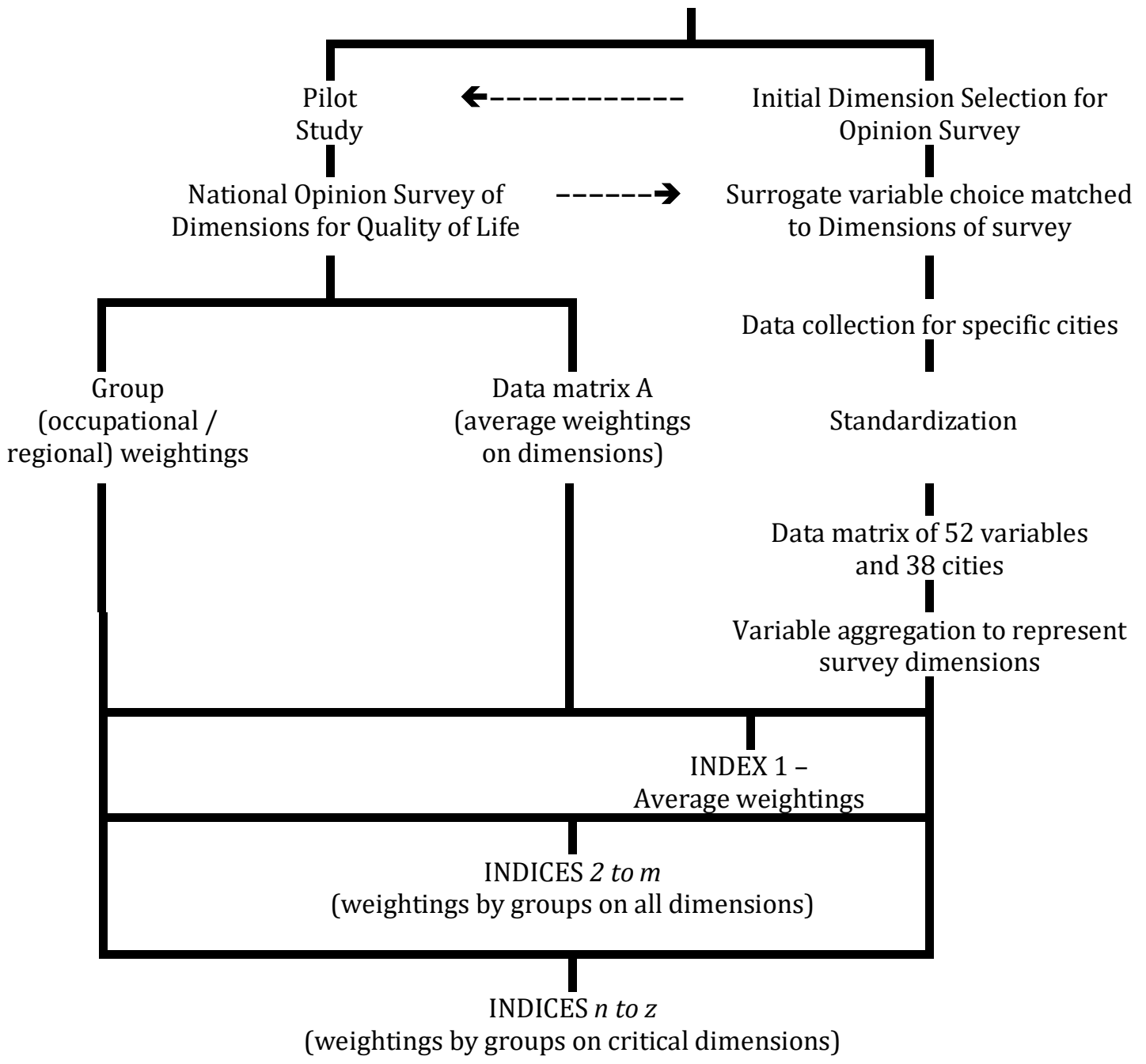

Source: Findlay et al. (1988a, p.97) 
Table 1: GQLG Dimensions and their Indicators, Weightings and Ranks

\begin{tabular}{|c|c|c|c|c|c|c|c|c|}
\hline \multirow[b]{2}{*}{ Dimension } & \multirow{2}{*}{$\begin{array}{c}\text { Percent } \\
\text { stating } \\
\text { dimension } \\
\text { was 'very } \\
\text { important' }\end{array}$} & \multicolumn{2}{|c|}{ National } & \multicolumn{2}{|c|}{ Scottish } & \multicolumn{2}{|c|}{$\begin{array}{c}\text { Significant Difference } \\
\text { of Perception }\end{array}$} & \multirow[b]{2}{*}{ Indicator/s } \\
\hline & & Weighting & Rank & Weighting & Rank & $\begin{array}{l}\text { Scottish } \\
\text { and Other } \\
\text { British }\end{array}$ & $\begin{array}{l}\text { Scottish } \\
\text { and South } \\
\text { East }\end{array}$ & \\
\hline Violent crime & 78.2 & 3.709 & 1 & 3.669 & 2 & & & Average number of violent crimes/population \\
\hline Non-violent crime & 76.9 & 3.693 & 2 & 3.706 & 1 & & & Average number of non-violent crimes/population \\
\hline Health facilities & 70.1 & 3.633 & 3 & 3.620 & 3 & & & $\begin{array}{l}\text { Number of available hospital beds/population } \\
\text { Number of GPs/population } \\
\text { Elderly Day Centre places/population over } 65 \text { years old }\end{array}$ \\
\hline Pollution & 55.3 & 3.407 & 4 & 3.314 & 6 & & $*$ & $\begin{array}{l}\text { Concentration of SO } 2 \text { in atmosphere } \\
\text { Proportion of area derelict or spoilt land }\end{array}$ \\
\hline Cost of Living & 54.8 & 3.390 & 5 & 3.400 & 4 & & & $\begin{array}{l}\text { Average rates bill per household } \\
\text { Average household heating costs } \\
\text { Average water rates bill } \\
\text { Average cost of weekly shopping basket }\end{array}$ \\
\hline Shopping Facilities & 49.4 & 3.308 & 6 & 3.321 & 5 & & & $\begin{array}{l}\text { Number of superstores/population } \\
\text { Diversity of high-order stores }\end{array}$ \\
\hline Racial Harmony & 52.0 & 3.239 & 7 & 3.271 & 7 & & & $\begin{array}{l}\text { People arrested of ethnic origin/all arrests June-July } \\
1981\end{array}$ \\
\hline Scenic Quality & 39.2 & 3.007 & 8 & 2.889 & 11 & & & Scenic Quality index (after Linton, 1968) \\
\hline $\begin{array}{l}\text { Cost of Owner Occupied } \\
\text { Houses }\end{array}$ & 50.0 & 2.992 & 9 & 2.737 & $13=$ & $*$ & $*$ & $\begin{array}{l}\text { Average cost of I-bedroom flat } \\
\text { Average cost of } 2 \text {-bedroom flat } \\
\text { Average cost of 3-bedroom semidetached house } \\
\text { Average cost of } 4 \text {-bedroom detached house }\end{array}$ \\
\hline Education Provision & 50.5 & 2.869 & 10 & 3.059 & 8 & & & $\begin{array}{l}\text { Pupil/Teacher ratio Primary schools } \\
\text { Pupil/Teacher ratio Secondary schools }\end{array}$ \\
\hline Employment Prospects & 52.6 & 2.826 & 11 & 3.030 & 9 & & & $\begin{array}{l}\text { Mobility Index of Employment Base } \\
\text { Diversity of employment base }\end{array}$ \\
\hline
\end{tabular}




\begin{tabular}{|c|c|c|c|c|c|c|c|c|}
\hline & & & & & & & & Employment change 1981-1984 \\
\hline Wage Levels & 49.6 & 2.822 & 12 & 2.933 & 10 & & & $\begin{array}{l}\text { Average weekly wage - males } \\
\text { Average weekly wage - females }\end{array}$ \\
\hline Unemployment & 44.2 & 2.729 & 13 & 2.791 & 12 & & & $\begin{array}{l}\text { Percentage Unemployment } 1986 \\
\text { Percentage Long-term Unemployed } 1986 \\
\text { Change in Unemployment 1982-1986 }\end{array}$ \\
\hline Climate & 29.5 & 2.638 & 14 & 2.737 & $13=$ & & $*$ & $\begin{array}{l}\text { Average annual temperature } \\
\text { Annual range of temperature } \\
\text { Average number of sunshine hours per day } \\
\text { Average number of wet days per annum }\end{array}$ \\
\hline Sport Facilities & 33.1 & 2.629 & 15 & 2.556 & 17 & & & Number sports and leisure clubs/population \\
\hline Travel to Work Time & 37.7 & 2.516 & 16 & 2.581 & 16 & & & $\begin{array}{l}\text { Distance by rail in } 30 \text { minutes (1700-1800) } \\
\text { Motorway provision/number of people driving to work } \\
\text { Percentage population walking to work } \\
\text { Proportion of population living and working in city }\end{array}$ \\
\hline Leisure Facilities & 24.2 & 2.477 & 17 & 2.419 & 18 & & & $\begin{array}{l}\text { Number orchestras, museums, art galleries/population } \\
\text { Number cinemas, theatres/population } \\
\text { Number of social clubs/population } \\
\text { Number of youth clubs/population 10-19 years old }\end{array}$ \\
\hline Quality of Council Houses & 29.3 & 2.204 & 18 & 2.649 & 15 & * & * & $\begin{array}{l}\text { Percentage houses lacking bath } \\
\text { Percentage houses lacking internal toilet } \\
\text { Percentage houses sharing internal toilet } \\
\text { Percentage with only I or } 2 \text { rooms }\end{array}$ \\
\hline Access to Council Housing & 27.6 & 2.045 & 19 & 2.368 & 19 & $*$ & $*$ & Waiting time to house those 'in need' \\
\hline Private Rented Housing & 20.8 & 1.916 & 20 & 2.231 & 20 & & * & Average cost of rented accommodation \\
\hline
\end{tabular}

Source: Morris et al., (1988), except column B, which is largely from Findlay et al. (xxxx); although as this omitted the racial harmony value, this is drawn from Findlay et al. (1988b) 
Figure 3: Mapping and ranking quality of life for Mainland Britain's largest cities

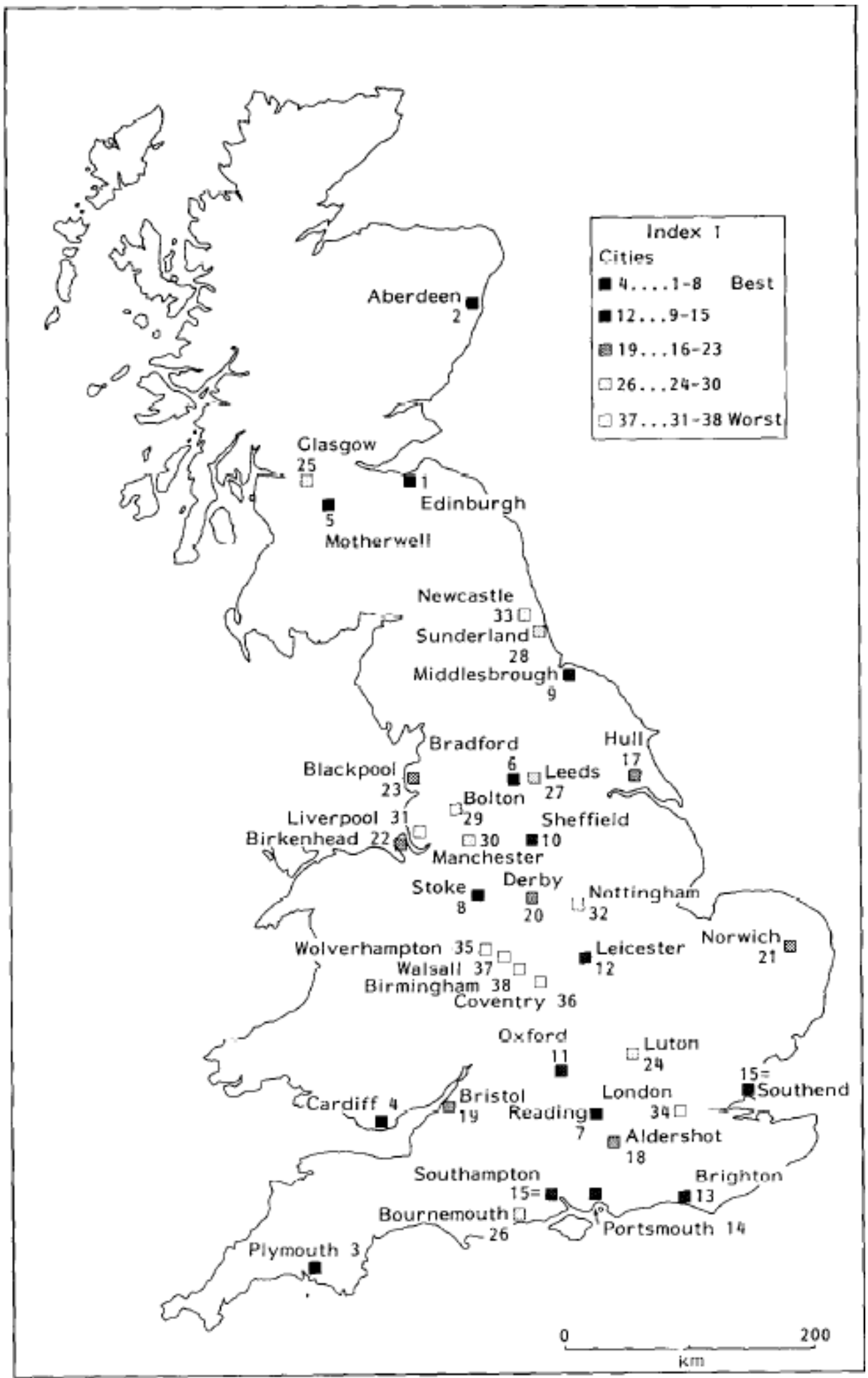

Source: Findlay et al., 1988, Figure 1, p.269. 
1 I had the good fortune to be a postgraduate student in the then Department of Geography and Topographic Science between 1990 and 1993. It was the days before the emergence of supervisory teams and while I benefitted from the supervision of Allan Findlay, Ronan supervised my closest postgraduate colleagues (Jim McCormick and Fiona Smith). Thirty years on and I can still recall three separate one-to-one conversations in which Ronan imparted words of wisdom mid-stairwell ("get your words in" before turning your hand to other academic tasks - advice that has haunted me ever since; a discussion about academic ideas being cyclical; and a candid exchange in which Ronan opined that quality of life research had "run its course"). I was a member of the Applied Population Research Unit (of which the Glasgow Quality of Life Group was a subgroup), but not the GQLG; I joined the Department when the Director of the GQLG (Robert Rogerson) was appointed to the University of Strathclyde and the GQLG came to a natural end, as its members thereafter pursued their own interests independently.

${ }^{2}$ Robert Rogerson (personal communication) credits Ronan with enabling the GQLG to explore further how local authorities and city councils could utilise the quality of life rankings to aid their competitive advantage, noting that one of the successes of the GQLG research was an active engagement with local councils and officials, assisting them in place marketing and developing news ways to use quality of life to engage with citizens.

3 Glasgow Action was a group that largely comprised the city's business leaders. It sought to work with local and national public bodies (Glasgow District Council, Strathclyde Regional Council and the Scottish Development Agency) in order to realize the potential of Glasgow city centre (Boyle, 1989). It was influenced by Gordon Cullen's (1983) The Potential of Glasgow City Centre report and was consistent with what was being promoted by the UK Government at that time, notably Action for Cities (Department of Environment and Department of Employment, 1987)

${ }^{4}$ In 1989, a larger national opinion survey of 2225 people was administered to generate new weightings in advance of the study of District Councils. Although some differences can be discerned between 1987 and 1989, the overarching conclusion is that there is stability in public opinion (Rogerson et al., 1990a).

546 indicators were used in the 1989 research with District Councils (Rogerson et al., 1990a).

${ }^{6}$ Stockton-on-Tees might be considered an exception, commissioning GQLG to produce a bespoke report despite being ranked 131 of 145 among District Councils (Rogerson et al., 1990b). 